\title{
Identifikasi Serangan Serangga Hama di Pertanaman Padi (Oryza Sativa L.) di Lahan Persawahan Tinggarjaya
}

\author{
Identification of Insect Pest Attacks on Rice Plantation (Oryza Sativa L.) \\ in Tinggarjaya Rice Fields
}

\author{
Agillia Anjani ${ }^{1}$, Teguh Pribadi ${ }^{2}$, Ardiana Kartika $\mathbf{B}^{3}$ \\ ${ }^{1,2,3}$ Fakultas Pertanian dan Perikanan, Universitas Muhammadiyah Purwokerto
}

\begin{tabular}{l} 
ARTICLE INFO \\
\hline Article history: \\
DOI: \\
10.30595/pspfs.v2i.184 \\
Submitted: \\
July 29, 2021 \\
Accepted: \\
Sept 10, 2021 \\
Published: \\
Nov 10, 2021 \\
\hline
\end{tabular}

Keywords:

Rice Crops, Identify Indect

Pest, Generative Stage

\begin{abstract}
Rice crops is included into the family of Graminae that produces seeds from China. Rice Plant is the crops that produce rice, consumed approximately by $90 \%$ from the whole citizens of Indonesia as the main food. This study aims to identify indect pest attacks in rice plantations in Tinggarjaya rice fields. From the results of the research that has been carried out, various kinds of insect pests were found in the Tinggarjaya rice fields. The main pests found were brown planthopper (N. Iguens), rice bug (Leptocorixa acuta), green grasshopper (Oxya serville), ground bedbug (Scotinophara coarctata F.), seed fly (Atherigona exigua), false white pest (Nymphula depunctalis guene), and green grasshopper (Atractomorpha crenulata). Each pest a different population density. Not all pests can be found at every stage of rice plant growth. The largest pest population was found in the generative stage.
\end{abstract}

This work is licensed under a Creative Commons Attribution 4.0 International License.

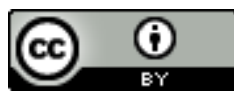

\section{Corresponding Author:}

Agillia Anjani

Fakultas Pertanian dan Perikanan, Universitas Muhammadiyah Purwokerto

Email: agilliaanjani7@gmail.com

\section{PENDAHULUAN}

Padi merupakan bahan makanan pokok masyarakat Indonesia dan sangat banyak dibudidayakan oleh masyarakat Indonesia. Salah satu kendala utama dalam budidaya tanaman padi sawah adalah adanya serangan hama. Serangan hama dilahan persawahan dapat mengakibatkan terjadinya penurunan produksi yang cukup berarti. Masalah kerusakan tanaman akibat serangan tanaman akibat serangan hama merupakan bagian budidaya pertanian sejak manusia mengusahakan pertanian ribuan tahun yang lalu (Pracaya, 1992).

Padi sawah dibudidayakan pada kondisi tanah tergenang. Penggenangan tanah akan mengakibatkan perubahan-perubahan sifat kimia tanah yang akan mempengaruhi pertumbuhan tanaman padi. Perubahanperubahan kimia tanah sawah yang terjadi setelah penggenangan antara lain antara lain : penurunan kadar oksigen dalam tanah, penurunan potensial redoks, perubahan $\mathrm{pH}$ tanah, reduksi besi $(\mathrm{Fe})$ dan mangan $(\mathrm{Mn})$, peningkatan suplai dan ketersediaan nitrogen (Tim Pusat Penelitian Tanah dan Agroklimat, 2000).

Padi (Oryza sativa L.) merupakan tanaman pangan yang menghasilkan beras, dikonsumsi kurang lebih $90 \%$ dari keseluruhan penduduk Indonesia sebagai makanan pokok (Saragih, 2001). Kebutuhan beras sebagai bahan makanan pokok penduduk Indonesia mengalami peningkatan sebesar 2,23\% per tahun (Arafah dan Sirappa, 2003).

Kebutuhan beras terus meningkat karena peningkatan jumlah penduduk yang tidak diimbangi dengan produksi yang cukup. Kebutuhan beras di Indonesia mencapai 32 juta ton sedangkan produksi nasional 
maksimal hanya mencapai sekitar 31,5 juta ton/tahun (Darma, 2007). Peningkatan produksi padi dengan pengembangan teknologi yang ada mutlak untuk dapat mendukung ketahanan pangan di Indonesia.

Organisme pengganggu tanaman (OPT) adalah setiap organisme yang dapat mengganggu pertumbuhan dan atau perkembangan tanaman sehingga tanaman menjadi rusak, pertumbuhannya terhambat, dan atau mati. UU No. 12 tahun 1992 tentang Sistem Budidaya Tanaman menyatakan bahwa "Organisme Pengganggu Tanaman (OPT) adalah "Semua Organisme yang dapat merusak, mengganggu kehidupan atau menyebabkan kematian tumbuhan"'(Sembel, 2012).

Hama dan penyakit tersebut belum dapat dikendalikan secara optimal sehingga mengakibatkan kerugian yang cukup besarbaik berupa kehilangan hasil, penurunan mutu serta menurunkan pendapatan petani (Tulung, 2004). Di Indonesia lebih dari $50 \%$ kerugian yang didapatkan petani akibat dari serangan hama.

Serangga pada areal tanaman padi di seluruh dunia dilaporkan lebih dari 800 spesies serangga dan 100 spesies ( $12,5 \%$ ) merupakan serangga hama pada tanaman padi dan sisanya (700 spesies serangga) dilaporkan sebagai serangga penyerbuk, predator, parasitoid dan serangga netral. Serangga hama penting tanaman padi sebanyak 20 spesies termasuk penggerek batang, ganjur, wereng daun dan wereng tanaman yang dapat menyebabkan kerusakan secara langsung maupun tidak langsung dengan transmisi berbagai penyakit pada pertanaman. Serangga merusak bagian-bagian tanaman dengan menggigit dan mengunyah jaringan tanaman, menghisap cairan batang dan biji padi. Kerusakan yang disebabkan serangga pada tanaman mengakibatkan terganggunya fisiologi tanaman sehingga produksi tanaman lebih rendah (Ane et. al., 2015).

\section{METODE PENELITIAN}

\section{Lokasi}

Penelitian dilaksanakan di Desa Tinggarjaya, Kecamatan Jatilawang, Kabupaten Banyumas, Jalan Nasional III, 53174, dan identifikasi serangga dilakukan di Laboratorium Pengamatan Hama dan Penyakit Tanaman (LPHP) Banyumas.

\section{Waktu Penelitian}

Penelitian dilaksanakan pada tanggal 26 Januari sampai dengan 23 Februari 2021.

\section{Bahan dan Alat}

Bahan yang dibutuhkan adalah tanaman padi, imago serangga hama yang tertangkap, alkohol, formalin. Untuk peralatan yang dibutuhkan adalah alat tulis, camera hp, kotak serangga, jaring penangkap serangga, pinset, buku kunci identifikasi serangga, alat tulis dan alat-alat lainnya yang mendukung penelitian ini.

\section{Metode Analisis}

\subsection{Penentuan Lokasi Penelitian}

Sebelum kegiatan dilakukan, dilakukan survei lokasi lahan untuk menentukan tempat pengambilan sampel.Setiap lahan ditentukan tiga petakan sawah dengan ukuran 20 x 15 m. Kemudian dibagi lima sub plot pengamatan dibuat garis diagonal dengan ukuran 3 × 3 meter.

\subsection{Pengambilan Sampel}

Perangkap jaring terbuat dari kain kasa bening yang mudah diayunkan untuk menangkap serangga yang dapat terbang di lahan pertanaman. Penangkapan serangga dengan perangkap jaring dilakukan pada pagi hari pukul 07.00-09.00 WIB dengan 10 kali pengayunan pada setiap titik sampling. serangga yang tertangkap kemudian dikumpulkan dan dipisahkan serta di identifikasi secara langsung di lapangan lalu dimasukkan ke dalam kotak serangga, serangga yang tidak dapat di identifikasi secara langsung di lapangan dimasukkan ke dalam botolsampel dan selanjutnya dibawa ke Laboratorium Pengamatan Hama dan Penyakit Tanaman untuk di identifikasi dan disajikan dalam bentuk tabel.

Pengambilan sampel imago dilakukan pada pagi hari, dengan cara penyapuan 10 kali ayunan ganda pada lima sub plot pertanaman padi sawah yang telah ditentukan.Pengambilan sampel ini dilakukan dua kali ulangan dengan interval waktu satu minggu pada tanaman berumur 31 - 45 hari. Imago serangga yang terjaring dimasukan ke dalam kotak serangga kemudian diamati dan dilakukan perhitungan jumlah individu. Tata letak sampel di lokasi penelitian sebagai berikut :

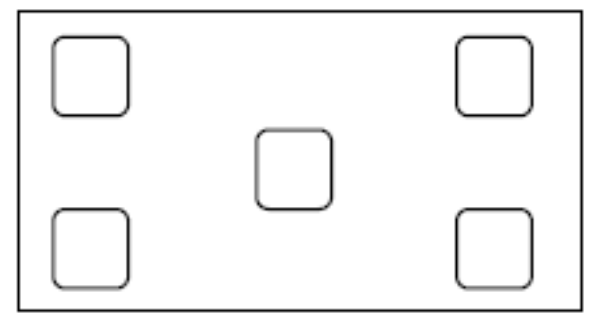

Gambar 1. Tata letak sampel dalam lokasi penelitian 
Keterangan :

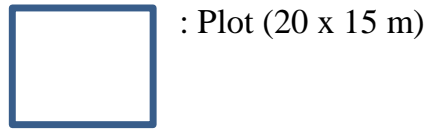

$\square:$ Sub Plot $(3 \times 3 \mathrm{~m})$

\subsection{Variabel yang diamati}

Pengamatan intensitas serangan dilakukan pada tanaman padi fase vegetatif, berdasarkan gejala serangan hama. Setiap sub plot dibuat garis diagonal ditentukan 10 rumpun tanaman padi untuk diamati, setiap rumpun yang memiliki gejala dihitung sebagai rumpun yang terserang. Variabel yang diamati berupa presentase kerusakan tanaman padi akibat serangan serangga hama.

\section{HASIL dan PEMBAHASAN}

\section{Hama Utama pada Padi di Lahan Persawahan}

Hama utama yang ditemukan adalah wereng batang coklat ( $N$. Iugens), walang sangit (Leptocorixa acuta), belalang hijau (Oxya serfville), kepinding tanah (Scotinophara coarctata F.), lalat bibit (Atherigona exigua), hama putih palsu (Nymphula depunctalis guene), dan belalang hijau (Atractomorpha crenulata). Setiap hama memiliki kepadatan populasi yang berbeda-beda. Tidak semua hama dapat ditemukan pada setiap tahap pertumbuhan tanaman padi. Populasi hama terbesar ditemukan pada stadia generatif.

Wereng Coklat. N. Iugens merupakan hama utama padi disawah yang memakan getah jaringan tanaman dan menyebabkan kerusakan ringan sampai berat pada tanaman padi disawah. Gejala serangan dari $N$. Iugens yaitu daun menguning dan kering (hopperburn). Hopperburn awalnya berbentuk lingkaran yang menunjukan pola penyebaran $N$. Iugens dimulai pada satu titik, kemudian menyebar ke segala arah dalam bentuk lingkaran.

Tabel 1. Populasi Hama Wereng Batang Coklat

\begin{tabular}{ccccc}
\hline Minggu Ke- & $\begin{array}{c}\text { Luas } \\
(\mathrm{m})\end{array}$ & Sisa serangan & Tambah serangan & Keadaan serangan \\
\hline Minggu 1 & $300 \mathrm{~m}$ & - & 10 & 10 \\
Minggu 2 & $300 \mathrm{~m}$ & - & 20 & 20 \\
\hline
\end{tabular}

Dari data yang dihasilkan pada minggu ke 1 terdapat serangan hama batang coklat sebanyak $10 \%$ dan dilakukan pengendalian dengan menggunakan pestisida kimia sebanyak $10 \%$ pada rumpun padi yang terkena serangan dan memiliki keadaan serangan $10 \%$ dengan intensitas serangan yang sangat ringan. Berbeda dengan data yang dihasilkan pada minggu ke 2 terdapat serangan hama batang coklat sebanyak $20 \%$ dan dilakukan pengendalian dengan menggunakan pestisida kimia sebanyak $21 \%$ pada rumpun padi yang terkena serangan dan memiliki keadaan serangan $20 \%$ dengan intensitas serangan yang sangat ringan. Hal ini dikarenakan oleh faktor internal dan eksternal yang dapat memacu perkembangbiakan hama batang coklat tersebut.

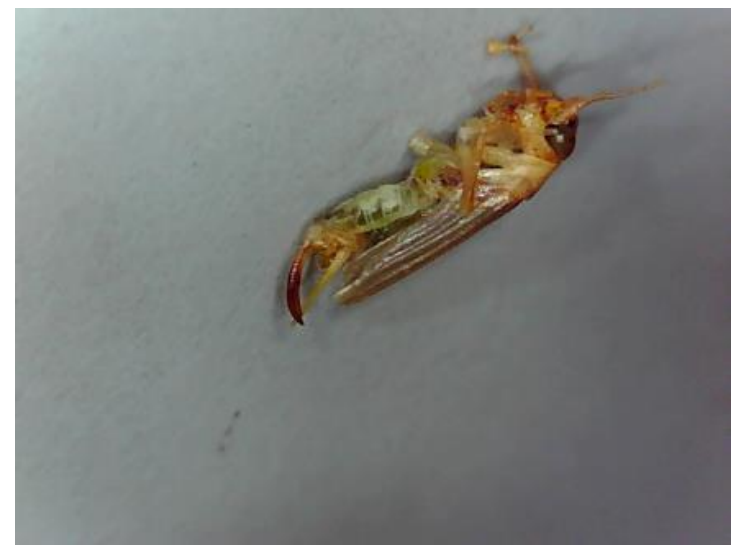

Walang sangit. (Leptocorixa acuta) merupakan salah satu hama utama yang menyerang tanaman padi. Hama ini ditemukan pada waktu padi mulai matang susu. Walang sakit menghisap cairan tanaman dari tangkai bunga (paniculae) dan juga cairan buah padi yang masih pada tahap masak susu sehingga menyebabkan 
tanaman kekurangan hara dan menguning (klorosis), pada bagian buah padi yang terserang buah padi menjadi hampa dan berubah warna menjadi kecoklatan.

Walang sangit merusak bulir padi pada fase pemasakan. Mekanisme merusaknya yaitu menghisap butiran gabah yang sedang mengisi. Apabila diganggu, maka serangga akan mempertahankan diri dengan mengeluarkan bau. Walang sangit merusak tanaman ketika mencapai fase berbunga sampai matang susu.

Tabel 2. Populasi Hama Walang Sangit

\begin{tabular}{ccccc}
\hline Minggu Ke- & $\begin{array}{c}\text { Luas } \\
(\mathrm{m})\end{array}$ & Sisa serangan & Tambah serangan & Keadaan serangan \\
\hline Minggu 1 & 300 & - & 40 & 30 \\
Minggu 2 & 300 & - & 50 & 20 \\
\hline
\end{tabular}

Dari data yang dihasilkan pada minggu ke 1 terdapat serangan hama wereng coklat sebanyak $40 \%$ dan dilakukan pengendalian dengan menggunakan pestisida kimia sebanyak $10 \%$ pada rumpun padi yang terkena serangan dan memiliki keadaan serangan 30\% dengan intensitas serangan ringan. Berbeda dengan data yang dihasilkan pada minggu ke 2 terdapat serangan hama walang sangit sebanyak $50 \%$ dan dilakukan pengendalian dengan menggunakan pestisida kimia sebanyak $10 \%$ pada rumpun padi yang terkena serangan dan memiliki keadaan serangan $20 \%$ dengan intensitas serangan yang sangat ringan. Hal ini dikarenakan oleh faktor internal dan eksternal yang dapat memacu perkembangbiakan hama walang sangit.

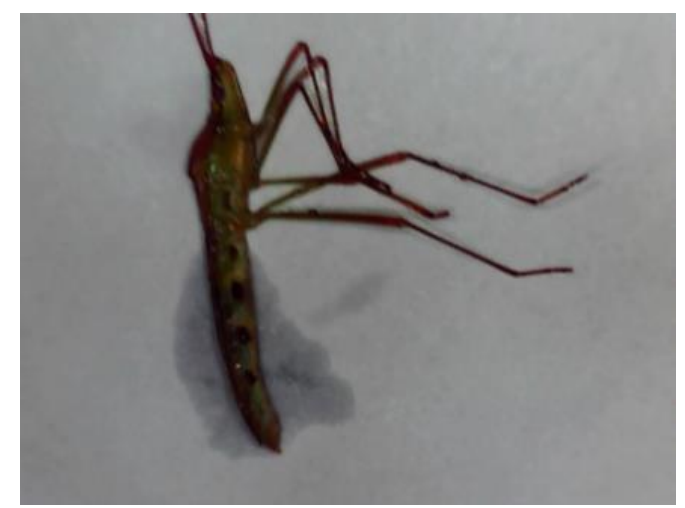

Belalang hijau. (Oxya serfville) merusak padi dengan cara memakan bagian daun, kemunculan hama belalang biasanya terjadi secara terus menerus dari awal padi ditanam sampai musim panen. Namun dalam pengelolaan ekosistem normal kerusakan yang ditimbulkan tidak begitu berarti karena kebanyakan belalang pada tanaman padi berukuran kecil, sehingga daun padi yang dimakan tidak terlalu banyak.

Tabel 3. Populasi Hama Belalang Hijau

\begin{tabular}{ccccc}
\hline Minggu Ke- & $\begin{array}{c}\text { Luas } \\
(\mathrm{m})\end{array}$ & Sisa serangan & Tambah serangan & Keadaan serangan \\
\hline Minggu 1 & 300 & - & 5 & 3 \\
Minggu 2 & 300 & - & 2 & 3 \\
\hline
\end{tabular}

Dari data yang dihasilkan pada minggu ke 1 terdapat serangan belalang hijau sebanyak 5\% dan tidak dilakukan pengendalian dan memiliki keadaan serangan 3\% dengan intensitas yang sangat ringan. Berbeda dengan data yang dihasilkan pada minggu ke 2 terdapat serangan hama belalang hijau sebanyak $2 \%$ dan tidak dilakukan pengendalian dan memiliki keadaan serangan 3\% dengan intensitas serangan yang sangat ringan. Hal ini dikarenakan oleh faktor internal dan eksternal yang dapat memacu perkembangbiakan hama belalang hijau. 


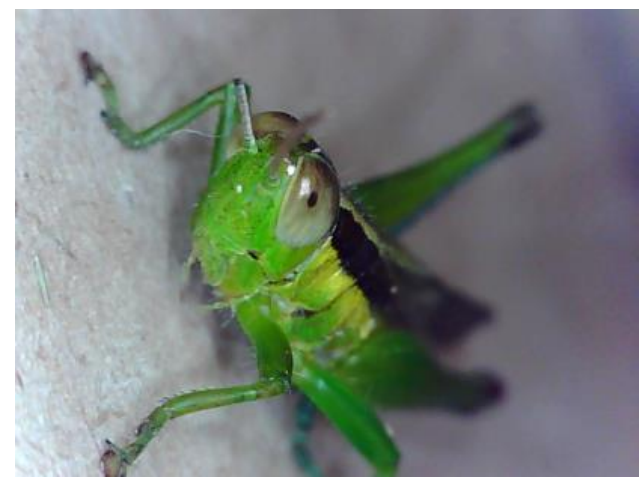

Kepinding tanah. (Scotinophara coarctata F.) menimbulkan gejala kerusakan yaitu di daerah sekitar lubang bekas hisapan berubah warna menjadi coklat menyerupai penyakit blas. Daun menjadi kering dan menggulung secara membujur. Penghisapan oleh kepinding tanah pada fase anakan menyebabkan jumlah anakan berkurang dan pertumbuhan terhambat.

Tabel 4. Populasi Hama Kepinding Tanah

\begin{tabular}{ccccc}
\hline Minggu Ke- & $\begin{array}{c}\text { Luas } \\
(\mathrm{m})\end{array}$ & Sisa serangan & Tambah serangan & Keadaan serangan \\
\hline Minggu 1 & 300 & - & 2 & 0 \\
Minggu 2 & 300 & - & 0 & 0 \\
\hline
\end{tabular}

Dari data yang dihasilkan pada minggu ke 1 terdapat serangan kepinding tanah sebanyak 2\% dan tidak dilakukan pengendalian dan memiliki keadaan serangan 0\% dengan intensitas yang sangat ringan. Berbeda dengan data yang dihasilkan pada minggu ke 2 terdapat serangan kepinding tanah tidak ditemukan pada rumpun yang diamati pada saat minggu pertama.

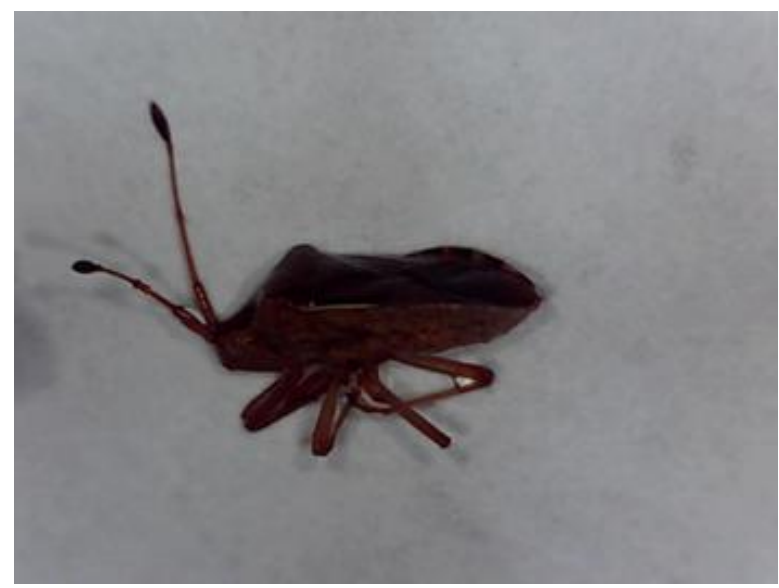

Lalat bibit. (Atherigona exigua) menyerang tanaman padi yang baru ditanam pindah pada sawah yang selalu tergenang. Stadia hama yang merusak tanaman padi adalah larvanya. Larva lalat bibit berwarna kuning kehijauhijauan yang tembus cahaya, berada dibagian tengan daun yang masih menggulung. Larva bergerak kebagian tengah tanaman merusak jaringan baian dalam sampai titik tumbuh daun. Gejala kerusakan adalah bercakbercak kuning yang dapat dilihat disepanjang tepi daun yang baru muncul dan daun yang terserang mengalami perubahan bentuk. Telur diletakan pada permukaan atas daun, berwarna keputih-putihan dan berbentuk lonjong seperti pisang. Siklus hidupnya selama 4 minggu.

Tabel 5. Populasi Hama Lalat Bibit

\begin{tabular}{ccccc}
\hline Minggu Ke- & $\begin{array}{c}\text { Luas } \\
(\mathrm{m})\end{array}$ & Sisa serangan & Tambah serangan & Keadaan serangan \\
\hline Minggu 1 & 300 & - & 3 & 1 \\
Minggu 2 & 300 & - & 0 & 0 \\
\hline
\end{tabular}

Dari data yang dihasilkan pada minggu ke 1 terdapat serangan lalat bibit sebanyak 3\% dan tidak dilakukan pengendalian dan memiliki keadaan serangan $1 \%$ dengan intensitas yang sangat ringan. Berbeda 
dengan data yang dihasilkan pada minggu ke 2 terdapat serangan lalat bibit tidak ditemukan pada rumpun yang diamati pada saat minggu pertama.

Tanaman yang terserang anakannya menjadi berkurang dan serangan berat dapat memperlambat fase pematangan 7-10 hari. Tanaman pada dasarnya dapat mengkompenseasi asalkan tidak ada serangan hama lainnya atau tekanan lingkungan yang mempengaruhi.

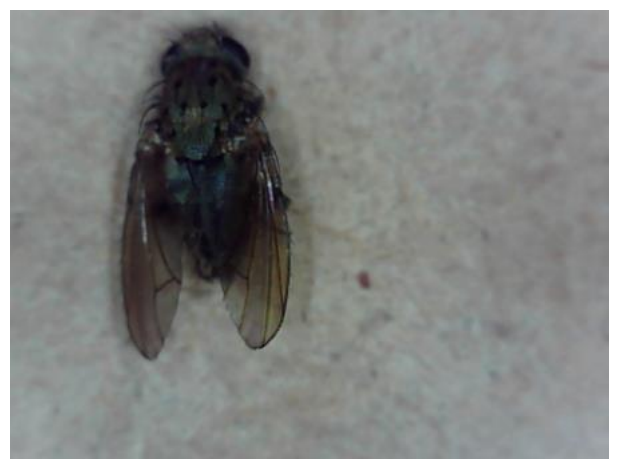

Hama Putih Palsu. (Nymphula depunctalis guene) menimbulkan gejala serangan pada permukaan bawah daun berupa garis memanjang berwarna daun. Hal tersebut disebabkan oleh aktivitas mengorok yang dilakukan oleh hama ini. Selain itu, kerusakan pada daun yang paling khas yaitu daun terpotong seperti digunting. Daun yang terpotong akan digunakan oleh hama tersebut untuk dibuat seperti gulungan yang digunakan larva untuk membungkus dirinya dengan benang-benang sutra. Tingkat ambang ekonomi adalah lebih dari $25 \%$ daun rusak atau 10 daun rusak perumpun.

Tabel 6. Populasi Hama Putih Palsu

\begin{tabular}{ccccc}
\hline Minggu Ke- & $\begin{array}{c}\text { Luas } \\
(\mathrm{m})\end{array}$ & Sisa serangan & Tambah serangan & Keadaan serangan \\
\hline Minggu 1 & 300 & - & 5 & 1 \\
Minggu 2 & 300 & - & 3 & 2 \\
\hline
\end{tabular}

Dari data yang dihasilkan pada minggu ke 1 terdapat serangan hama putih palsu sebanyak 5\% dan tidak dilakukan pengendalian dan memiliki keadaan serangan 1\% dengan intensitas yang sangat ringan. Berbeda dengan data yang dihasilkan pada minggu ke 2 terdapat serangan hama putih palsu sebanyak $3 \%$ dan tidak dilakukan pengendalian sehingga memiliki keadaan serangan $2 \%$.

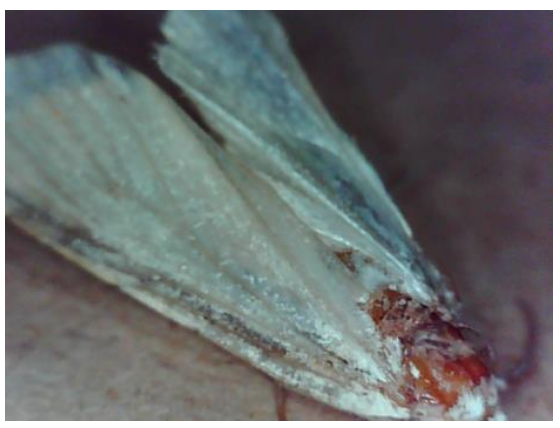

Belalang hijau. (Atractomorpha crenulata) merupakan salah satu anggota dari kelompok serangga (kelas insekta). Serangga dapat berperan sebagai pemakan tumbuhan, sebagai parasitoid, sebagai predator, pemakan bangkai, sebagai penyerbuk dan sebagai penular bibit penyakit tertentu.

Tabel 7. Populasi Hama Belalang Hijau

\begin{tabular}{ccccc}
\hline Minggu Ke- & $\begin{array}{c}\text { Luas } \\
(\mathrm{m})\end{array}$ & Sisa serangan & Tambah serangan & Keadaan serangan \\
\hline Minggu 1 & 300 & - & 5 & 3 \\
Minggu 2 & 300 & - & 2 & 3 \\
\hline
\end{tabular}

Dari data yang dihasilkan pada minggu ke 1 terdapat serangan belalang hijau sebanyak 5\% dan tidak dilakukan pengendalian dan memiliki keadaan serangan 3\% dengan intensitas yang sangat ringan. Berbeda dengan data yang dihasilkan pada minggu ke 2 terdapat serangan hama belalang hijau sebanyak $2 \%$ dan tidak 
dilakukan pengendalian dan memiliki keadaan serangan 3\% dengan intensitas serangan yang sangat ringan. Hal ini dikarenakan oleh faktor internal dan eksternal yang dapat memacu perkembangbiakan hama belalang hijau.

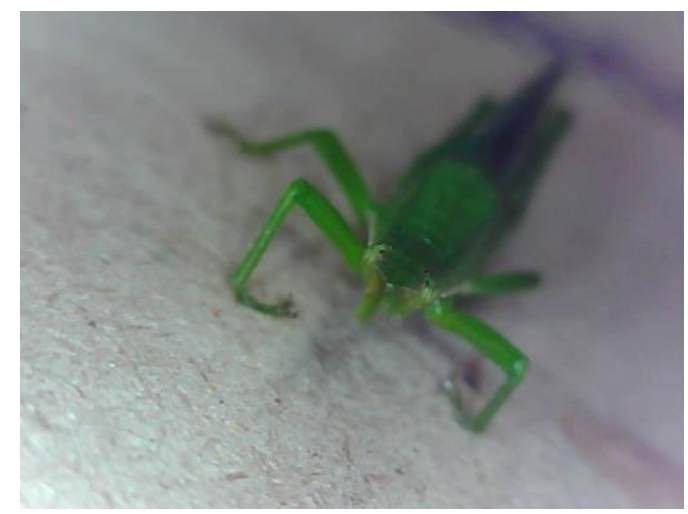

\section{KESIMPULAN DAN SARAN}

\section{Kesimpulan}

Hama utama yang ditemukan di lokasi persawahan di Tinggarjaya adalah wereng batang coklat $(N$. Iugens), walang sangit (Leptocorixa acuta), belalang hijau (Oxya serfville), kepinding tanah (Scotinophara coarctata F.), lalat bibit (Atherigona exigua), hama putih palsu (Nymphula depunctalis guene), dan belalang hijau (Atractomorpha crenulata). Hama yang ditemukan cukup beragam meskipun memiliki kepadatan populasi yang rendah. Hal ini disebabkan oleh adanya musuh alami, penggunaan varietas tahan, pemupukan, dan teknik budidaya, faktor cuaca (suhu, kelembaban, dan curah hujan), dan penggunaan pestisida konvensional.

\section{Saran}

Dengan adanya berbagai jenis hama yang dapat menurunkan produktivitas yang tinggi pada tanaman padi yang akan dipanen karena adanya serangan hama-hama tersebut. Sehingga harus dilakukan pengendalian yang dilakukan pengendalian secara mekanik, pengendalian secara kimiawi, maupun pengendalian secara fisik.

\section{DAFTAR PUSTAKA}

Ane, N. Vi. dan Mubasharhusain. 2015. Diversity of Pest in Major Rice Growing Areas of the World. Journal of Entomology and Zoology Studies 4(1) : 36-41.

Arafah dan Sirappa M. P. 2003. Kajian penggunaan jerami dan pupuk N, P, dan K pada lahan sawah irigasi. BPTP Sulawesi Selatan. J. Ilmu Tanah dan Lingkungan 4 (1): 15-24.

Darma., M D I. 2007.Swasembada Beras, Sebuah Impian?. http://www.balipost.co.id/balipost cetaK/2007/9/17/o2.htm. Di akses tanggal 14 April 2013.

Pracaya. 1992. Hama dan Penyakit Tanaman. Penerbit Penebar Swadaya. Jakarta.

Sembel, D. T., 2012. “Dasar-Dasar Perlindungan Tanaman”, Fakultas Pertanian UNSRAT Manado.

Tim Pusat Penelitian Tanah dan Agroklimat. 2000. Sumber daya Lahan Indonesia dan Pengelolaannya. Badan Penelitian dan Pengembangan Pertanian. Departemen Pertanian, Bogor.

Tulung, M. 2004. Sistem Peramalan Hama. Fakultas Pertanian UNSRAT Manado. 